\title{
PENGHAPUSAN PENDAFTARAN MEREK BERDASARKAN GUGATAN PIHAK KETIGA
}

\author{
Agus Mardianto \\ Fakultas Hukum Universitas Jenderal Soedirman Purwokerto, Jawa Tengah \\ e-mail: agus.basir@yahoo.co.id
}

\begin{abstract}
The right of a trademark is an exclusive right granted by government. A registered trademark can be cancelled from the General List of Trademark. Cancellation of registration of a trademark can be claimed by a third party through a dispute to a Commercial Court based on article 61 paragraph (2) letter $b$ of Trademark Law 2001. This research is aimed at studying the use of article 61 paragraph (2) letter b of Trademark Law 2001 as the base of dispute for cancelation of the registration of a trademark by a third party, and studying the legal consequences of a trademark cancelation. A qualitative juridicial normative method with descriptive analyses approaches was used to analyze secondary data derived from documents of decisions of Commercial Court of Central Jakarta Number 06/Merek/205/PN.Niaga.JKT.PST and documents of decisions of Supreme Court of the Republic of Indonesia Number 031K/N/HaKI2005. The result of the research showed that the application of article 61 paragraph (2) letter b of Trademark Law 2001 for the base of decision of the judges of Commercial Court of Central Jakarta was inappropritate. In judging at the use of a trademark, the judges only looked at the inconsistency of writtting styles or fonts or colours, but not taking into considerations of the purpose and intention of the parties that claimed the dispute. Cancelation of regitration of a trademark based on the dispute of a third party automatically resulted in the termination of legal protection of the related trademark.
\end{abstract}

Keywords: trademark, cancelation of a trademark, third party, good intention, Commercial Court

Abstrak

Hak merek dagang merupakan hak eksklusif yang diberikan oleh pemerintah. Sebuah merek dagang terdaftar dapat dibatalkan dari Daftar Umum Merek. Pembatalan pendaftaran merek dagang dapat diklaim oleh pihak ketiga melalui persengketaan kepada Pengadilan Umum berdasarkan pasal 61 ayat (2) huruf b UU Merek 2001. Penelitian ini bertujuan untuk mempelajari penggunaan pasal 61 ayat (2) huruf b UU Merek tahun 2001 sebagai dasar untuk pembatalan sengketa tentang pendaftaran merek dagang oleh pihak ketiga, dan mempelajari konsekuensi hukum dari pembatalan merek dagang. Metode normatif dengan pendekatan kualitatif yurisdiksi analisis deskriptif digunakan untuk menganalisis data sekunder diperoleh dari dokumen keputusan dari Pengadilan Niaga Jakarta Pusat Nomor 06/Merek/205/PN.Niaga.JKT.PST dan dokumen keputusan Mahkamah Agung Republik Indonesia Nomor $031 \mathrm{~K} / \mathrm{N} / \mathrm{HaKI} 2005$. Hasil penelitian menunjukkan bahwa penerapan pasal 61 ayat (2) huruf b UU Merek 2001 untuk dasar keputusan hakim Pengadilan Niaga Jakarta Pusat inappropritate. Dalam menilai pada penggunaan merek dagang, para hakim hanya melihat inkonsistensi writtting gaya atau font atau warna, tapi tidak memperhatikan pertimbangan tujuan dan niat dari pihak yang menyatakan sengketa. Pembatalan dari pembatalan merek dagang berdasarkan sengketa pihak ketiga secara otomatis mengakibatkan berakhirnya perlindungan hukum merek dagang terkait.

Kata Kunci: Merk, Pembatalan Pendaftaran Merk, Pihak Ketiga, Niat Baik, Pengadilan Niaga

Pendahuluan

Peran merek dalam perdagangan global menjadi sangat penting terutama untuk menjaga persaingan usaha yang sehat. ${ }^{1}$ Merek

Direktorat Jenderal Hak Kekayaan Intelektual (bekerja sama dengan ECAP II), 2006, Buku Panduan Hak Kekayaan Intelektual, Jakarta: Ditjen HKI DEPKUMHAM RI, hlm. 261 adalah tanda yang berupa gambar, nama, kata, huruf-huruf, angka-angka, susunan warna, atau kombinasi dari unsur-unsur tersebut yang memiliki daya pembeda dan digunakan dalam kegiatan perdagangan barang atau jasa. Hak atas Merek adalah hak eksklusif yang diberikan oleh negara kepada pemilik merek yang ter- 
daftar dalam Daftar Umum Merek untuk jangka waktu tertentu.

Pendaftaran atas merek merupakan suatu keharusan bagi pemilik merek, akan tetapi hak atas merek hanya akan diberikan oleh Direktorat Merek jika permintaan pendaftaran merek oleh pemohon merek dilakukan dengan itikad baik. Unsur itikad baik dalam suatu permintaan pendaftaran merek merupakan unsur yang penting, seperti tercantum dalam Pasal 4 UU Merek 2001 yang menyebutkan bahwa merek tidak dapat didaftar atas dasar per-mohonan yang diajukan oleh pemohon yang beritikad tidak baik. Pemohon yang beritikad baik adalah pemohon yang mendaftarkan mereknya secara jujur dan layak tanpa ada niat apapun untuk membonceng, meniru, atau menjiplak ketenaran merek pihak lain demi kepentingan usahanya yang berakibat kerugian pada pihak lain itu atau menimbulkan kondisi persaingan curang, mengecoh atau menyesatkan konsumen. ${ }^{2}$ Pengertian itikad baik menurut J. Satrio, itikad baik dapat dibedakan dalam dua pengertian, yaitu itikad baik subjektif dan itikad baik objektif. Itikad baik subjektif (subjectief goeder trouw) adalah berkaitan dengan apa yang ada dalam pikiran manusia, yaitu berkaitan dengan sikap batinnya apakah yang bersangkutan sendiri menyadari bahwa kehendaknya itu bertentangan dengan itikad baik. Itikad baik objektif (objectief goeder trouw) adalah kalau pendapat umum mengungkapkan tindakan begitu bertentangan dengan itikad baik. $^{3}$

Tidak semua merek dapat didaftarkan, hanya tanda-tanda yang memenuhi syarat di bawah ini yang dapat didaftar sebagai merek, seperti mempunyai daya pembeda; merupakan tanda pada barang dagang atau jasa yang dapat berupa gambar (lukisan), nama, kata, hurufhuruf, angka-angka, susunan warna atau kombinasi dari unsur-unsur tersebut; tanda tersebut tidak bertentangan dengan peraturan per-

Yayasan Klinik HAKI, 2002, Kompilasi Undang-Undang Hak Cipta, Paten Merek dan Terjemahan KonvensiKonvensi di Bidang Hak Kekayaan Intelektual, Bandung: Citra Aditya Bakti, hlm. 506.

3 J. Satrio, 2000, Hukum Perikatan, Perikatan yang Lahir Dari Perjanjian. Bandung: Citra Aditya Bakti, hlm. 179. undang-undangan yang berlaku, moralitas agama, kesusilaan, atau ketertiban umum; dan tanda tersebut juga tidak mempunyai persamaan dengan merek lain yang terdaftar terlebih dahulu, atau merek terkenal

Meskipun Undang-undang sudah mengatur ketentuan pendaftaran merek sedemikian rupa, namun pada prakteknya seringkali timbul beberapa masalah dalam pemeriksaan merek. Salah satu yang menonjol adalah yang berkaitan dengan "persamaan". Bagaimana menentukan ada tidaknya suatu persamaan merek, baik persamaan pada pokoknya maupun persamaan pada keseluruhannya seperti diatur dalam Pasal 6 ayat (1) huruf a adalah hal yang tidak mudah.

Ada doktrin yang dapat dipergunakan untuk menentukan ada tidaknya persamaan merek menurut Amalia Rooseno, yaitu doktrin entireties similiar dan doktrin nearly resembles. ${ }^{4}$ Doktrin entireties similiar menganggap persamaan keseluruhan elemen adalah standar, dalam hal ini merek yang diminta untuk didaftarkan merupakan copy reproduksi merek orang lain. Ajaran ini dianggap terlalu kaku dan tidak dapat melindungi kepentingan pemilik merek, khususnya untuk merek terkenal.

Doktrin nearly resembles menganggap suatu merek mempunyai persamaan pada pokoknya dengan merek orang lain jika pada merek tersebut terdapat kemiripan (identical) atau hampir mirip dengan merek orang lain, yang dapat didasarkan pada kemiripan gambar, susunan kata, warna atau bunyi. Faktor yang paling pokok dalam doktrin ini adalah pemakaian merek yang mempunyai persamaan pada pokonya ini dapat menimbulkan kebingungan yang nyata (actual confusion) atau menyesatkan (decieve) masyarakat konsumen. Seolah-olah merek tersebut berasal dari sumber atau produsen yang sama, sehingga di dalamnya terlihat unsur iktikad tidak baik untuk membonceng ketenaran merek milik orang lain. $^{5}$

Emmy Yuhassari, 2004, Hak Kekayaan Intelektual dan Perkembangannya, Jakarta: Pusat Pengkajian Hukum, hal 206-207

5 Ibid. 
Teori lain yang dapat dikemukakan adalah teori holistic approach dan teori dominacy. Teori ini untuk menentukan ada tidaknya persamaan merek harus dilihat secara keseluruhan, baik dari bunyinya, artinya, ejaannya maupun dari tampilannya. Teori dominancy menentukan adanya persamaan merek antara merek yang satu dengan yang lainnya cukup diambil unsur yang dianggap paling dominan dari merek tersebut.

Merek yang sudah terdaftar dalam Daftar Umum Merek, masih dapat dimintakan penghapusan pendaftaran merek tersebut. Penghapusan pendaftaran merek dari Daftar Umum Merek dapat dilakukan atas prakarsa Direktorat Jenderal Hak Kekayaan Intelektual atau berdasarkan permohonan pemilik merek yang bersangkutan atau berdasarkan gugatan penghapusan pendaftaran merek yang diajukan oleh pihak ketiga.

Penghapusan pendaftaran merek atas prakarsa Direktorat Jenderal Hak Kekayaan Intelektual atau berdasarkan gugagatan pihak ketiga menurut Pasal 61 ayat (2) UU Merek 2001 dapat dilakukan jika merek tidak digunakan selama 3 (tiga) tahun berturut-turut dalam perdagangan barang dan/atau jasa sejak tanggal pendaftaran atau pemakaian terakhir; atau merek digunakan untuk jenis barang dan/atau jasa yang tidak sesuai dengan jenis barang dan/atau jasa yang dimohonkan pendaftaran, termasuk pemakaian merek yang tidak sesuai dengan merek yang didaftar.

Gugatan penghapusan pendaftaran merek oleh pihak ketiga menurut Henry Soelistyo harus dilihat siapa sebenarnya yang beriktikad baik dan yang beriktikad tidak baik, karena filosofi dari pendaftaran merek adalah perlawanan terhadap iktikad tidak baik. ${ }^{6}$ Iktikad baik tersebut antara lain dalam kepemilikan atau pemakaiannya. ${ }^{7}$

Sengketa antara Gunawan Chandra melawan PT. ASTRA HONDA MOTOR, menarik

Legal Review Nomor: 41 Tahun IV Maret 2006, hal 37. Cita Citrawinda Priapantja, 2000. Perlindungan Merek Terkenal Di Indonesia. Makalah disampaikan pada Program Pelatihan "Training of Teachers" Angkatan VIII yang diselenggarakan oleh Fakultas Hukum Universitas Indonesia tanggal 23 November 2000. untuk mengetahui bagaimanakah penerapan Pasal 61 ayat (2) huruf b UU Merek 2001 yang dipakai sebagai dasar alasan gugatan penghapusan pendaftaran merek, serta akibat hukum penghapusan pendaftaran merek berdasarkan gugatan pihak ketiga karena dalam Putusannya Nomor 06/Merek/2005.PN.Niaga. JKT.PST, Pengadilan Niaga jakarta Pusat telah menerima dan mengabulkan gugatan Penggugat. Dalam tingkat kasasi gugatan Penggugat ditolak oleh Mahkamah Agung dengan putusan Nomor 031 K/N/HAKI/2005.

\section{Permasalahan}

Ada 2 (dua) permasalahan yang diajukan dalam artikel ini. Pertama mengenai penerapan Pasal 61 ayat (2) huruf b Undang-Undang Nomor 15 Tahun 2001 tentang Merek dalam Keputusan Pengadilan Niaga Jakarta Pusat Nomor 06/Merek/2005.PN.Niaga.JKT.PST jo. Keputusan Mahkamah Agung Nomor 031/K/N/HAKI/ 2005; dan kedua mengenai akibat hukum penghapusan pendaftaran merek berdasarkan gugatan pihak ketiga.

\section{Metode Penelitian}

Penelitian ini menggunakan metode pendekatan yuridis normatif dengan spesifikasi penelitian deskriptif analisis, dengan menggunakan data sekunder yang diperoleh melalui studi dokumen atas data pokok berupa Putusan Pengadilan Niaga Jakarta Pusat Nomor 06/ Merek/2005/PN.Niaga.JKT.PST dan Putusan Mahkamah Agung Republik Indonesia Nomor 031 $\mathrm{K} / \mathrm{N} / \mathrm{HaKI} / 2005$. Kemudian data yang di-peroleh dianalisis secara normatif kualitatif.

\section{Pembahasan}

Perkara yang terdaftar dengan Nomor 06/Merek/2005.PN.Niaga.JKT.PST berkaitan dengan pemakaian merek yang tidak sesuai dengan merek yang didaftar. Dalam hal ini merek-merek KARISMA 125, KARISMA 125 D,dan KARISMA milik PT. Astra Honda Motor yang sudah terdaftar pada Direktorat Jenderal Hak Kekayaan Intelektual Departemen Hukum Dan Hak Asasi Manusia Republik Indonesia dengan Nomor Pendaftaran 520497, 520496 dan 520150 
tertanggal 30 Oktober 2002. Pemakaian merek yang tidak sesuai dengan merek yang didaftar dapat berakibat penghapusan pendaftaran merek tersebut dari Daftar Umum Merek. Celah inilah yang dimanfaatkan oleh Gunawan Chandra yang sedang mengajukan permohonan pendaftaran mereknya KRISMA 125 EFC pada Direktorat Jenderal Hak Kekayaan Intelektual Departemen Hukum Dan Hak Asasi Manusia Republik Indonesia dengan Nomor Agenda D.09.2004.00019 tertanggal 26 Maret 2004 untuk mengajukan gugatan penghapusan pendaftaran terhadap merek-merek milik PT. Astra Honda Motor seperti tersebut di atas.

Berkaitan dengan penghapusan pendaftaran merek, Pasal 61 UU Merek 2001 menentukan bahwa penghapusan pendaftaran merek dari Daftar Umum Merek dapat dilakukan atas prakarsa Direktorat Jenderal Hak Kekayaan Intelektual atau berdasarkan permohonan pemilik merek yang bersangkutan. Penghapusan pendaftaran merek atas prakarsa Direktorat Jenderal Hak Kekayaan Intelektual menurut Pasal 61 ayat (2) UU Merek 2001 dapat dilakukan jika merek tidak digunakan selama 3 (tiga) tahun berturut-turut dalam perdagangan barang dan/atau jasa sejak tanggal pendaftaran atau pemakaian terakhir; atau merek digunakan untuk jenis barang dan/atau jasa yang tidak sesuai dengan jenis barang dan/atau jasa yang dimohonkan pendaftaran, termasuk pemakaian merek yang tidak sesuai dengan merek yang didaftar.

Penghapusan pendaftaran merek dapat pula diajukan oleh pihak ketiga dalam bentuk gugatan kepada Pengadilan Niaga berdasarkan Pasal 63 UU Merek 2001, dengan alasan-alasan sebagaimana dimaksud dalam Pasal 61 ayat (2) huruf a dan huruf $b$. Berdasarkan hal tersebut Gunawan Chandra mengajukan gugatan penghapusan pendaftaran merek kepada Pengadilan Niaga Jakarta Pusat dengan alasan sebagaimana dimaksud dalam Pasal 61 ayat (2) huruf, yaitu pemakaian merek yang tidak sesuai dengan merek yang didaftar, dimana ketidaksesuaian dalam penggunaan tersebut meliputi ketidaksesuaian dalam bentuk penulisan kata atau huruf atau ketidaksesuaian dalam penggunaan warna yang berbeda.

Pengadilan Niaga Jakarta Pusat dalam Putusan Nomor: 06/Merek/2005/PN.Niaga.JKT. PST. Memutuskan menerima dan mengabulkan Gugatan Penggugat; menyatakan merek-merek KARISMA 125, KARISMA 125 D, dan KARISMA dengan Nomor-nomor Pendaftaran : 520497, 520496, 520150, untuk melindungi barang di kelas 12 telah digunakan tidak sesuai dengan merek-merek yang didaftarkan tersebut dalam peredaran/di pasaran; dan menyatakan hapus pendaftaran merek-merek KARISMA 125, KARISMA 125 D, dan KARISMA dengan Nomor Pendaftaran : 520497, 520496, 520150, untuk melindungi barang di kelas 12 dengan segala akibat hukumnya.

Penulis tidak sependapat dengan Putusan tersebut di atas, karena menurut penulis seharusnya Majelis Hakim tidak menerima/ menolak gugatan Gunawan Chandra. Latar belakang Gunawan Chandra mengajukan gugatan penghapusan pendaftaran merek adalah adanya teguran/somasi dari pihak Astra Honda Motor terhadap merek KRISMA milik Gunawan Chandra yang sedang mengajukan pendaftaran merek. Menurut Astra Honda Motor merek KRISMA mempunyai persamaan pada pokoknya dengan merek KARISMA yang sudah terdaftar. Menurut penulis kalau tidak ada teguran/ somasi dari Astra Honda Motor mungkin Gunawan Chandra tidak akan mengajukan gugatan penghapusan pendaftaran merek. Jadi menurut penulis ada iktikad tidak baik dari Gunawan Chandra dalam mengajukan gugatan penghapusan pendaftaran merek, karena tidak ada kepentingan Gunawan Chandra yang dirugikan dari merek KARISMA yang terdaftar.

Mahkamah Agung dalam Putusannya Nomor $031 \mathrm{~K} / \mathrm{N} / \mathrm{HaKl} / 2005$ secara tegas menolak gugatan Gunawan Chandra dengan pertimbangan bahwa Merek KRISMA 125 EFC yang baru diajukan pendaftarannya oleh Gunawan Chandra, mempunyai persamaan pada pokoknya dengan merek terkenal dan terdaftar KARISMA milik PT. ASTRA HONDA MOTOR baik dalam kata, bunyi ucapan maupun jenis barang yang dilindungi, selain itu gugatan penghapusan merek 
barulah diajukan setelah ada somasi/teguran atas pemakaian merek KRISMA tersebut dengan demikian ada itikad tidak baik untuk membonceng ketenaran merek terkenal dan terdaftar KARISMA.

Secara umum jangkauan pengertian iktikad tidak baik menurut Amalia Rooseno meliputi perbuatan "penipuan" (fraud), rangkaian "menyesatkan" (misleading) orang lain, serta tingkah laku yang mengabaikan kewajiban hukum untuk mendapat keuntungan. Bisa juga diartikan sebagai perbutan yang tidak dibenarkan secara sadar untuk mencapai suatu tujuan yang tidak jujur (dishonesthy purpose). Dalam pengkajian merek, setiap perbuatan peniruan, reproduksi, mengkopi, membajak atau membonceng kemasyuran merek orang lain dianggap sebagai perbuatan pemalsuan, penyesatan atau memakai merek orang lain tanpa hak (unauthorized use) yang secara harmonisasi dalam perlindungan merek dikualifikasikan sebagai persaingan curang (unfair competition) serta dinyatakan sebagi perbuatan mencari kekayaan secara tidak jujur (unjust enrichment). ${ }^{8}$ Berkaitan dengan hal tersebut menurut Henry Soelistyo, dalam kasus gugatan penghapusan pendaftaran merek oleh pihak ketiga harus dilihat siapa sebenarnya yang beriktikad baik dan yang beriktikad tidak baik, karena filosofi dari pendaftaran merek adalah perlawanan terhadap iktikad tidak baik. ${ }^{9}$

Putusan Majelis Hakim Pengadilan Niaga Jakarta Pusat tersebut di atas terlihat jelas bahwa Majelis Hakim mendasarkan putusannya pada Pasal 61 ayat 2 huruf $b$ yaitu tentang pemakaian merek yang tidak sesuai dengan merek yang didaftar. Menurut penulis penerapan Pasal 61 ayat 2 huruf b dalam kasus di atas adalah kurang tepat karena Majelis Hakim dalam menilai tentang pemakaian merek yang tidak sesuai dengan merek yang didaftar hanya melihat pada ketidaksesuaian dalam penggunaan bentuk penulisan kata atau huruf atau penggunaan warna yang berbeda. Menurut penulis sebaiknya Majelis Hakim mempertimbang-

\footnotetext{
Emmy Yuhassari, op. cit., hlm 221

Legal Review Nomor : 41 Tahun IV Maret 2006, loc.cit.
}

kan atau melihat apakah ketidaksesuaian dalam penggunaan bentuk penulisan kata atau huruf atau penggunaan warna yang berbeda itu akan merugikan pihak lain atau tidak, misalnya penggunaan bentuk penulisan kata atau huruf atau penggunaan warna yang berbeda menyerupai atau memiliki persamaan dengan merek orang lain yang sudah terdaftar terlebih dahulu. Dengan kata lain apakah tampilan dari merek tersebut menyerupai atau memiliki persamaasn dengan merek orang lain yang sudah terdaftar terlebih dahulu.

Mahkamah Agung berpendapat Majelis Hakim Pengadilan Niaga Jakarta Pusat telah salah menerapkan hukum (Pasal 61 ayat (2) huruf b UU Merek 2001) dengan pertimbangan bahwa merek adalah tanda yang berupa gambar, nama, kata huruf-huruf, angka-angka, susunan warna atau kombinasi dari unsur-unsur tersebut yang memiliki daya pembeda dan dipergunakan dalam kegiatan perdagangan barang atau jasa. Sehingga dalam menilai apakah penggunaan merek yang tidak sesuai dengan merek yang didaftar seharusnya Majelis Hakim tidak hanya melihat pada ketidaksesuaian dalam bentuk penulisan kata atau huruf atau penggunaan warna yang berbeda dengan etiket merek yang terdaftar, melainkan harus pula memperhatikan apa yang dimaksud dengan merek (yang terdaftar) menurut UndangUndang lebih-lebih terhadap suatu merek terkenal in casu merek terdaftar KARISMA.

Putusan Mahkamah Agung dalam Rekonpensi menyatakan bahwa PT. ASTRA HONDA MOTOR adalah satu-satunya pemilik pendaftar pertama dan pemegang hak khusus atas merekmerek terkenal KARISMA beserta variasinya, menurut Penulis Putusan Mahkamah Agung tersebut sangat tepat, karena merek-merek tersebut sudah terdaftar pada Direktorat Jenderal Hak kekayaan Intelektual dengan Nomor pendaftaran 520497, 520496 dan 520150, sehingga PT. ASTRA HONDA MOTOR mempunyai Hak atas Merek tersebut. Hal tersebut sesuai dengan pendapat Ahmad $M$. Ramli yang menyatakan bahwa merek diakui keberadaannya berdasarkan stelsel konstitutif, dengan kata lain tidak ada perlindungan tanpa 
pendaftaran. ${ }^{10}$ Sedangkan Budi Agus Riswandi dan $M$. Syamsudin berpendapat bahwa Pemegang merek, baru akan diakui atas kepemilikan mereknya kalau merek itu dilakukan pendaftaran. Hal ini sesuai dengan prinsip yang dianut dalam UU Merek Indonesia, yakni first to file principle, bukan first come, first out. ${ }^{11}$ Hal tersebut sesuai dengan ketentuan Pasal 3 UU Merek 2001 yang menyebutkan bahwa hak atas merek adalah hak eksklusif yang diberikan oleh negara kepada pemilik merek yang terdaftar dalam Daftar Umum Merek untuk jangka waktu tertentu dengan menggunakan sendiri merek tersebut atau memberikan izin kepada pihak lain untuk menggunakannya. ${ }^{12}$

Penulis sependapat dengan Putusan Mahkamah Agung yang menyatakan bahwa KARISMA beserta variasinya adalah merek terkenal. Walaupun mengenai definisi merek terkenal tidak ditentukan secara tegas dalam Undang-Undang, tetapi untuk dapat dikategorikan bahwa suatu merek sebagai merek yang sudah terkenal, penjelasan Pasal 6 ayat (1) huruf $b$ menyebutkan harus memperhatikan beberapa hal, di antaranya pengetahuan umum masyarakat mengenai merek tersebut di bidang usaha yang bersangkutan; reputasi merek terkenal yang diperoleh karena promosi yang gencar dan besar-besaran; investasi di beberapa negara di dunia yang dilakukan oleh pemiliknya; dan bukti pendaftaran tersebut di beberapa Negara

Putusan Mahkamah Agung dalam Rekonpensi yang menyatakan bahwa Gunawan Chandra secara tanpa hak telah menggunakan merek KARISMA dan KRISMA yang mempunyai persamaan pada pokoknya atau keseluruhan dengan merek-merek terkenal KARISMA terdaftar dan variasinya milik PT. ASTRA HONDA MOTOR adalah putusan yang sangat tepat.

Penjelasan Pasal 6 ayat (1) huruf a menegaskan bahwa yang dimaksud dengan per-

10 Ahmad M. Ramli, 2004. Cyberl Law dan HAKI Dalam Sistem Hukum Indonesia, Bandung: Refika Aditama, hlm. 11

11 Budi Agus Riswandi dan M. Syamsudin, 2004. Hak Kekayaan Intelektual dan Budaya Hukum, Jakarta: Raja Grafindo Persada, hlm. 85

12 Muhamad Firmansyah, 2008, Tata cara Mengurus HaKI, Jakarta: Visimedia, hlm. 50 samaan pada pokoknya adalah kemiripan yang disebabkan oleh adanya unsur-unsur yang menonjol antara merek yang satu dengan merek yang lain, yang dapat menimbulkan kesan adanya persamaan baik mengenai bentuk, cara penempatan, cara penulisan atau kombinasi antara unsur-unsur ataupun persamaan bunyi ucapan yang terdapat dalam merek-merek tersebut.

Doktrin nearly resembles menganggap suatu merek mempunyai persamaan pada pokoknya dengan merek orang lain jika pada merek tersebut terdapat kemiripan (identical) atau hampir mirip dengan merek orang lain, yang dapat didasarkan pada kemiripan gambar, susunan kata, warna atau bunyi. Faktor yang paling pokok dalam doktrin ini adalah pemakaian merek yang mempunyai persamaan pada pokoknya ini dapat menimbulkan kebingungan yang nyata (actual confusion) atau menyesatkan (decieve) masyarakat konsumen. Seolah-olah merek tersebut berasal dari sumber atau produsen yang sama sehingga di dalamnya terlihat unsur iktikad tidak baik untuk membonceng ketenaran merek milik orang lain. ${ }^{13}$

Penghapusan Pendaftaran Merek yang dilakukan atas prakarsa Direktorat Jenderal Hak Kekayaan Intelektual atau berdasarkan permohonan pemilik merek yang bersangkutan dicatat dalam Daftar Umum Merek dan diumumkan dalam Berita Resmi Merek. Sedangkan Penghapusan Pendaftaran Merek berdasarkan gugatan pihak ketiga akan dilakukan oleh Direktorat Jenderal Hak Kekayaan Intelektual apabila putusan pengadilan tentang hal tersebut telah diterima dan mempunyai kekuatan hukum tetap.

Saidin menyatakan bahwa apabila gugatan penghapusan pendaftaran merek diterima dan telah mempunyai kekuatan hukum yang tetap maka Direktorat Jenderal Hak Kekayaan Intelektual akan melaksanakan penghapusan merek yang bersangkutan dari Daftar Umum Merek dan mengumumkannya dalam Berita

13 Emmy Yuhassari, loc.cit. 
Resmi Merek. ${ }^{14}$ Menurut Rachmadi Usman, penghapusan pendaftaran merek berdasarkan gugatan pihak ketiga akan dilakukan oleh Direktorat Jenderal Hak Kekayaan Intelektual dengan cara mencoret merek yang bersangkutan dari Daftar Umum Merek. ${ }^{15}$ Selanjutnya Saidin berpendapat bahwa sejak tanggal pencoretan dari Daftar Umum Merek maka Sertifikat Merek yang bersangkutan dinyatakan tidak berlaku lagi. ${ }^{16}$ Dengan Penghapusan pendaftarn merek mengakibatkan berakhirnya perlindungan hukum merek yang bersangkutan ${ }^{17}$

\section{Penutup}

Berdasarkan hasil analisis terhadap penerapan Pasal 61 ayat (2) huruf b UU Merek 2001 terlihat bahwa penerapan Pasal 61 ayat (2) huruf b UU Merek 2001 yang menjadi dasar Putusan Majelis Hakim Pengadilan Niaga Jakarta Pusat dalam perkara gugatan penghapusan pendaftaran merek oleh pihak ketiga Putusan Nomor 06/Merek/2005/PN.Niaga.JKT. PST adalah kurang tepat. Majelis Hakim dalam menilai apakah penggunaan merek yang tidak sesuai dengan merek yang didaftar seharusnya tidak hanya melihat pada ketidaksesuaian dalam bentuk penulisan kata atau huruf atau penggunaan warna yang berbeda dengan etiket merek yang terdaftar, melainkan harus pula memperhatikan apa yang dimaksud dengan merek (yang terdaftar) menurut UndangUndang, terlebih terhadap suatu merek terkenal terdaftar KARISMA. Pemakaian merek terdaftar KARISMA dengan tampilan huruf dan warna yang berbeda tidak menimbulkan karakter yang berbeda dengan merek yang didaftar, sebab bunyi ucapan tetap sama dan tidak menimbulkan kesan karakter yang lain dari merek yang telah didaftar sehingga unsurunsur tersebut mempunyai daya pembeda dan

14 Saidin, 2007. Aspek Hukum Hak Kekayaan Intelektual (Intellectual Property Rights), Jakarta: RajaGrafindo Persada, hlm. 393

15 Rachmadi Usman, 2003. Hukum Hak Atas Kekayaan Intelektual : Perlindungan dan Dimensi Hukumnya di Indonesia, Bandung: Alumni, hlm. 362.

16 Saidin, op. cit, hlm. 394

17 Rachmadi Usman, op. cit, hlm. 362 karena merupakan merek menurut pengertian Pasal 1 angka UU Merek 2001.

Berdasarkan analisis terhadap akibat hukum penghapusan pendaftaran merek berdasarkan gugatan pihak ketiga apabila gugatan tersebut dikabulkan dan mempunyai kekuatan hukum tetap adalah penghapusan merek yang bersangkutan dari Daftar Umum Merek. Penghapusan pendaftaran merek dilakukan oleh Direktorat Jenderal Hak Kekayaan Intelektual dengan mencoret merek yang bersangkutan dari Daftar Umum Merek. Sejak tanggal pencoretan dari Daftar Umum Merek, sertifikat merek yang bersangkutan dinyatakan tidak berlaku lagi yang secara otomatis mengakibatkan berakhirnya perlindungan hukum atas merek yang bersangkutan.

Berdasarkan hasil analisis ditemukan bahwa Majelis Hakim dalam menilai tentang pemakaian merek yang tidak sesuai dengan merek yang didaftar hanya melihat pada ketidaksesuaian dalam penggunaan bentuk penulisan kata atau huruf atau penggunaan warna yang berbeda tanpa mempertimbangkan atau melihat apakah ketidaksesuaian dalam penggunaan bentuk penulisan kata atau huruf atau penggunaan warna yang berbeda itu akan merugikan pihak lain atau tidak. Majelis Hakim juga tidak melihat bahwa pihak ketiga yang mengajukan gugatan tersebut adalah pihak ketiga yang tidak berkepentingan dan beritikad tidak baik.

Berdasarkan hasil yang ditemukan dapat dikemukakan saran bahwa sebaiknya dalam memutus perkara gugatan penghapusan pendaftaran merek yang dilakukan oleh pihak ketiga berdasarkan Pasal 61 ayat (2) huruf b jo. Pasal 63 UU Merek 2001, Majelis Hakim harus mempertimbangkan atau melihat apakah ketidaksesuaian dalam penggunaan bentuk penulisan kata atau huruf atau penggunaan warna yang berbeda itu akan merugikan pihak lain atau tidak, dengan kata lain apakah penggunaan bentuk penulisan kata atau huruf atau penggunaan warna yang berbeda tersebut menyerupai atau memiliki persamaan pada pokoknya atau persamaan pada keseluruhannya dengan merek orang lain yang sudah terdaftar 
terlebih dahulu. Pihak ketiga yang mengajukan gugatan penghapusan pendaftaran merek haruslah pihak ketiga yang berkepentingan dan mempunyai itikad baik. Diharapkan Pemerintah dapat mengantisipasi permasalahan penampilan kemasan suatu produk yang diperdagangkan (trade dress) melalui revisi Undang-Undang Merek yang sekarang ada. 